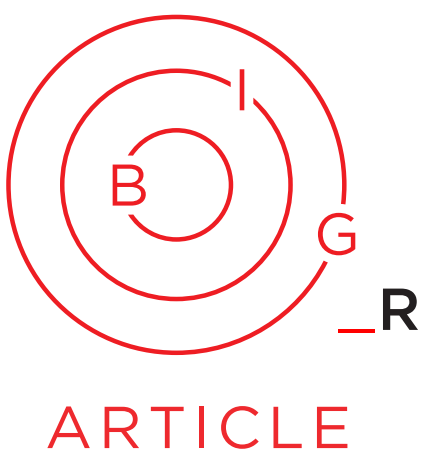

Borders in Globalization Review

Volume 1, Issue 1 (Fall 2019): 54-65

https://doi.org/10.18357/bigr11201919041

\title{
Aztlán: From Mythos to Logos in the American Southwest
}

\section{Toni Muñoz-Hunt *}

\begin{abstract}
This article advances the idea of "Aztlán" as a hybrid border identity that developed over time from ancient myth into a complex mode of social and political ontology. The cultural symbol of Aztec mythology was once the homeland of the Aztec people and eventually served a role in Aztec philosophy, functioning as truth for peoples throughout time, as seen in both Latin American and American philosophy and literature. It also helped the mixed-race Chicano/a population resist complete Americanization into the contemporary period, through the reclamation of original myth into a geopolitical homeland. The theory of "double hybridization," similar to "double colonization," must be further assessed and taken into consideration as the natural progression and understanding of Aztlán and border identity.
\end{abstract}

\section{Introduction}

Much of Latin American indigenous philosophy from the eighteenth to the twenty-first century can be attributed to Aztec philosophy, culture, and mythology. Aztlán is often understood as the mythical American Southwest and ancestral homeland of the Aztec people. The epicenter of this Aztec mythology and philosophy is the ancient peoples' desire for balance and unity in an ephemeral world. As explained in Nahuatl legends, Aztlán began when seven tribes from seven different caves came together before their migration to modern day Mexico City. Almost a thousand years later, Aztlán has traversed from its origins and mythos to a philosophy and logos. It was adopted as the Chicano/a homeland in the middle of the twentieth century during the Chicano/a Movement in the Civil Rights Era, after Alurista's acclaimed manifesto, "El Plan Espiritual de Aztlán," which advocated for Chicano/a nationalism and self-determination.
The article has four main sections. The first section explores the semiotic and philosophical significance of Aztlán as a mythical homeland to the Aztec people, prior to their departure and peregrination many centuries ago, to its reclamation during the 1960s into a geographical, geocultural, and geopolitical location between-but still separate from-the United States and Mexico (called the American Southwest). Through an interdisciplinary approach of anthropology, postcolonial theory, and mythology discourse, the second section examines how the diasporic flux of this indigenous population has interwoven a cultural and genetic tapestry of a mixed population as seen in its Aztec history and philosophy, and its evolution as a functioning myth through disruption, colonization, and hybridization. The third section analyzes Aztlán's integration from a historical and literary approach to the US-Mexico border and the eventual reclamation during the

* Toni Muñoz-Hunt is completing her PhD in Literature at The University of Texas at Dallas. Contact: toni@unityhunt.com 
Chicano Movement that has strengthened its foundations on either side of the modern imaginary boundary line. Finally, the concluding section demonstrates how, given an interdisciplinary understanding of Aztlán throughout time, this social phenomenon amongst the Chicano/a nation has evolved into hybridized ideology from "mythos to logos."

\section{Aztlán History}

In order to navigate the contradictions of the rhetorical notion of "Aztlán"-a term rebirthed from the Chicano Movement in the late 1960s-and whether or not it geographically and geoculturally relates to contemporary thought, Aztlán's literary symbology, its philosophical relevance, and debated meaning across time must be assessed. Anthropologists have discovered evidence of remains, dating as far back as 35,000-8000 BCE, from the Texas Southwest and Arizona regions (Barnouw and Lynn 1960, 186). According to anthropological research on "Indian languages, social organization, material culture, and origin myths," the Southern Arizona Cochise culture is credited with being the "parent culture of peoples as far apart as the Ute of Colorado and the Aztec of the Valley of Mexico" (Ellis 1968, 96). Further research shows that sometime after 1000 BCE, communication between the American Southwest and the Valley of Mexico increased, which was due in part to the Uto-Aztecan population migrating south while the cultivation of maize began to head north. Northern and southern populations were intersecting, and eventually, the "hunting-and-gathering Cochise culture" started to disappear, replaced by the more agrarian cultures of the "Mogollon, Hohokam, Anasazi, and Pueblos." Naturally, with trade came transculturation (Riley 1971, 286-287).

Around this time, according to Nahuatl (Aztec) legends, that seven Nahua tribes-Xochimilca, Tlahuica, Acolhua, Tlaxcalteca, Tepaneca, Chalca, and Mexica-from seven different caves and who all spoke the same Nahuatl language left their respective caves and settled in Aztlán, which became their homeland and a place for unification. Together, they became the "Mexicas" as they migrated south in search of their promised land. As interpreted from Aztec codices, their southward peregrination began around 1064 CE and ended when they encountered their prophetic vision of "an eagle, perched on a cactus, devouring a snake" in present-day Mexico City. Although most historiography focuses on the actual migration and establishment of city-states, the exact meaning of Aztlán is debated and has proven to be of great importance to indigenous peoples as indicated throughout time in various maps and codices. Some experts believe Aztlán means "place of white herons," while others inter- pret it more simply as a "place of whiteness" (Pina 1989, 19-28). Bob Hodge's and Vijay Mishra's article "Aboriginal Place" views the desert in Peter Skipper's cartographic painting, Jila Japingka, as partly absent owing to purposely chosen negative colors and the lighter color depicting a place of "abundance" (1991, 363). According to Walter Mignolo, in Mapa Sigüenza, the "spatial narrative of the Aztec peregrination from Aztlán to the Valley of Mexico" $(1995,368)$ is indicative of the negative and positive depictions often seen in indigenous maps during the pinturas period, or first period, which took place from 1540-1560. Mignolo explains that the geographical imprecision has been interpreted in the negative $(1995,368)$. The negative is reflective of what the Amerindians did not possess, versus the positive, which was reflective of what they did possess. It may be possible that Nahua people saw Aztlán, as a "place of whiteness," in the positive as a place of abundance and a place they possessed.

Whether Aztlán is a mythical or historical fact, it functioned as aww truth to the Aztec people, evidenced by the extensive Boturini Codex, now housed at Mexico's National Institute of Anthropology and History (Figure 1). It is one of the most important and longest surviving chronicles of the Mexica people from Aztlán to the city of Tenochtitlán.

The biggest fact of contention amongst historians and archeologists regarding Aztlán is whether it existed or if it were akin to some of New Spain's (Mexico) other mythical locations, like Cevola or Cibola, and the Seven Cities of Gold. Many archeologists have attempted to identify the original location of Aztlán but have failed to definitively locate the homeland of the Nahua people. Aztlán is believed to be northwestern Mexico or the American Southwest. These calculations were determined from letters and documents obtained from the Spanish conquistadors and explorers who navigated the region, but the location of Aztlán was not substantiated. After the Spanish annihilated the Aztec state, New Spain hegemonized the region, and the hybridized people along the border began to "vacillate between a self-identity as foreigners and a self-identity as natives" (Chávez 1989, 53). Consequently, one of the biggest issues concerning Latin America philosophy has been the history and identity of the Latin American people.

For most of the twentieth century, Latin American philosophy, like Aztlán, has been the subject of many heated debates concerning existence, identity, originality, and authenticity. When the Spanish explorers first arrived in the Americas, the Amerindians were scattered throughout the land and substantially divided into many diverse cultures, with many different languages. Eventually, 


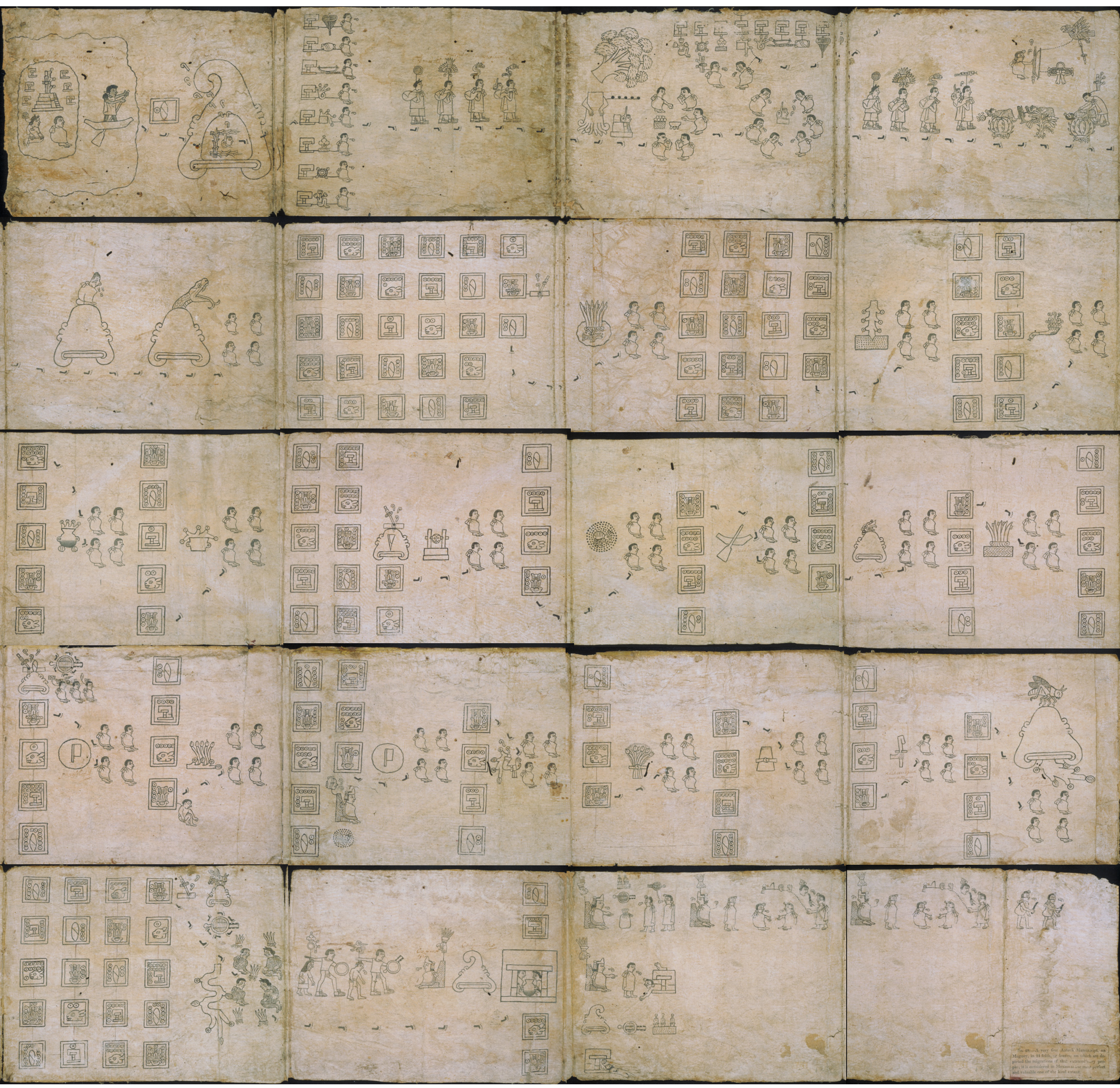

Figure 1. The Boturini Codex, housed at Mexico's National Institute of Anthropology and History. "The Boturini Codex is one of the most important surviving chronicles of the history of the Mexica people. Specifically, it details the journey of the Mexica from their mythical homeland of Aztlán, from which they were expelled, and the subsequent journey to the Valley of Mexico. This is where they eventually founded the city of Tenochtitlán (today Mexico City) and started their empire. The Boturini Codex is one of the most important surviving sources of this story. Considering the subject matter, it is also known as la Tira de la Peregrinación, the strip (of long paper) of the pilgrimage" (Boturini Codex [1530-1541]) 
the Spanish imposed a colonial unification on them, especially once Africans were brought in to supplement the labor shortage (Mann, 2005, p. 121). If a population is unwillingly put together, the authenticity of the works produced from that society is, therefore, questionable.

\section{Aztec Philosophy}

Although Latin American philosophy can be divided into five different periods-Pre-Columbian, Colonial, Independentist, Nationalist, and Contemporarymany scholars believe that the originality and authenticity of Latin American philosophy came before the Ameridian population was conquered and colonialized (Nuccetelli 2013). Much of what is understood from the pre-Columbian period came from text written after the Spanish conquest by colonists and missionaries, or from Christianized, Spanish, educated natives. However, the most authentic pre-Columbian sources are the Aztec codices.

In the Americas, Aztec philosophy was the most developed and, in many ways, was comparable to Ancient Greek philosophy. According to scholar James Maffie, this pre-Columbian civilization made attempts to explore the nature of reality and the limits of knowledge. Aztec philosophy as developed from Aztec culture, focused on dualism, monism, and aesthetics, and was centered on the quest for stability and balance in an ephemeral world. An example of this balance is the binary concept of Ometeotl, the unity of all things in the universe, even things in opposition, like light and dark, and life and death (Maffie 2014). Unity with dualistic expressions is similar to dialectical monism, where reality is a unified whole and can be expressed in dualistic terms, as seen in complementary polarities and present in both Western and Eastern philosophies (James 1963). In American Philosophy, William James's concept of a "block universe," did convey this Manichean notion of dualism but in a transitory world within an infinite system.

A "block universe" refers to the systematically predetermined reality from all aspects. Along with Charles Sanders Peirce, James founded the school of pragmatism, and in many ways critics viewed pragmatism similarly to relativism. Nevertheless, James believed that pragmatism was rooted in epistemological realism and the world exists independently and innately to our perceptions, and then, our senses reflect that understanding (James 1963). Thus, by James's interpretation, the meaning of truth relies on how it functions. Therefore, if Aztec philosophy is rooted in Aztec culture and it functions as a truth, then Aztlán, whether a myth or historical or geographical location acts as truth.
Other Aztec truths can be found in the transcultural influences that have been cultivated and Hispanicized through hybridization and are still in existence and often used today throughout the US. According to Rolando Romero of Feminism, Nation, and Myth: La Malinche, the majority of the maize derivatives come from the Aztec tradition, such as "corn tortillas, pinole, gorditas, tamales, pozole, menudo, enchiladas, tamales, and tacos." Maybe not as commonplace as the food items previously mentioned, there are also words within the border vernacular that have been acquired: "calco (shoe), cuate (friend), chante (home), and ruco (old man)" (Romero 2005, p. X). Many Aztec cross-cultural practices followed by the hybridized American Southwest people today originated from the Aztecs. One such belief is el ojo (the evil eye), which refers to a stranger's envious stare that would make a newborn child inexplicably sick. Mothers and babies wear colorful necklaces or display other noticeable trinkets to distract the stranger's gaze and ward off el ojo. Another common practice is having a niche or altar for saints within the home as a way to worship on a daily basis, and the use of brujeria (witchcraft) and curanderas (healers) as alternative wellness practices that came from the indigenous peoples. Popular folklore and legends along the American Southwest can be traced back to Aztec origins, as well. Two in particular are La Llorona and La Malinche (Lux and Vigil 1989, pp. 102-104). La Llorona and La Malinche, both women, are regarded as traitors and villains haunting an entire culture for generations, La Llorona for killing her children and La Malinche for being a vende or sellout to her native people (Romero 2005, p. 28). Reclamation of Aztlán is just another example of cross-cultural beliefs that have made their way into a hybridized ideology.

Aztlán functioned as the truth to the Aztec people and, over time, to the Chicano/a people. According to folklorist and scholar, Vladimir Yakovlevich Propp, the linear structural arrangement of a folklore or mythology is integral to the meaning and longevity of the story. He created the Propp Sequence in an effort to deconstruct the component of a successful story. The Propp Sequence consists of thirty-one functions in chronological order, and when the story and evolution of Aztlán is applied to it, it fulfills all thirty-one functions of the quest narrative, and thus, provides a glimpse of how Aztlán prevailed throughout centuries (Propp 1969) (Figure 2).

\section{US-Mexico Border History}

Analyzing the role of the mythology and legend of La Malinche is paramount to understanding US-Mexico Border history and the ultimate reworlding of Aztlán. Many people view her as the 


\begin{tabular}{|c|c|c|c|}
\hline & Function & Meaning & Aztlán \\
\hline 1 & Absentation & $\begin{array}{l}\text { The story begins with } \\
\text { damage or loss }\end{array}$ & $\begin{array}{l}\text { The } 7 \text { tribes are separated and speak various } \\
\text { languages. }\end{array}$ \\
\hline 2 & Interdiction & The hero must leave & The 7 tribes must leave their caves. \\
\hline 3 & Violation of Interdiction & The hero agrees & $\begin{array}{l}\text { The } 7 \text { tribes all decide to leave their respective } \\
\text { caves. }\end{array}$ \\
\hline 4 & Reconnaissance & Preliminary search & They leave their caves. \\
\hline 5 & Delivery & The meeting place & All 7 tribes come together in Aztlán. \\
\hline 6 & Trickery & Put to a test & $\begin{array}{l}\text { The } 7 \text { tribes receive a message to go on a journey } \\
\text { to a new homeland. }\end{array}$ \\
\hline 7 & Complicity & Acceptance of the test & All 7 tribes leave. \\
\hline 8 & Villainy or Lacking & $\begin{array}{l}\text { Mystical aid or message } \\
\text { is gifted }\end{array}$ & $\begin{array}{l}\text { The } 7 \text { tribes receives signs that will guide them to } \\
\text { their final location. }\end{array}$ \\
\hline 9 & Mediation & Intervention & There are stops along the way. \\
\hline 10 & Beginning Counteraction & Encounter an adversary & The tribes encounter Coxcoxtli. \\
\hline 11 & Departure & Defeated & $\begin{array}{l}\text { The tribes leave again and start going their } \\
\text { separate ways. }\end{array}$ \\
\hline 12 & $\begin{array}{l}\text { First Function of the } \\
\text { Donor }\end{array}$ & Things turn around & The tribes split apart and settle in new locations. \\
\hline 13 & Hero's Reaction & Everything falls into place & The city-states are established. \\
\hline 14 & $\begin{array}{l}\text { Receipt of a Magical } \\
\text { Agent }\end{array}$ & Magic appears & Aztec empire finds its home. \\
\hline 15 & Guidance & Saved & Aztec empire is prosperous thanks to the gods. \\
\hline 16 & Struggle & A villain comes & Spanish Conquistadors come. \\
\hline 17 & Branding & A marking happens & The Aztecs are branded as savages. \\
\hline 18 & Victory & Villain is defeated & Savages are defeated. \\
\hline 19 & Liquidation & Issues are resolved & $\begin{array}{l}\text { Spanish mix with Amerindians and the Mexican } \\
\text { mestizo/a is born. }\end{array}$ \\
\hline 20 & Return & Journey back & Many mestizo/as head north back to Aztlán. \\
\hline 21 & Pursuit & A new adversary pursues & $\begin{array}{l}\text { Aztlán has become the Southwest Border and } \\
\text { taken over by the Americans. }\end{array}$ \\
\hline 22 & Rescue & Salvation & $\begin{array}{l}\text { The Treaty of Guadalupe Hidalgo defines the } \\
\text { Border. }\end{array}$ \\
\hline 23 & Unrecognized Arrival & A new home is found & $\begin{array}{l}\text { The Border people must choose which side of the } \\
\text { Border they will remain on. }\end{array}$ \\
\hline 24 & Unfounded Claims & False claims & America takes over much of the Southwest. \\
\hline 25 & Difficult Task & Put through a test & $\begin{array}{l}\text { The former inhabitants of Aztlán have been } \\
\text { displaced. }\end{array}$ \\
\hline 26 & Solution & Fight & The Border people fight for their homeland. \\
\hline 27 & Recognition & Acceptance of identity & $\begin{array}{l}\text { Over the centuries, the Border people have become } \\
\text { a new people, no longer native. They are mixed. } \\
\text { They are a mestizo/a nation. }\end{array}$ \\
\hline 28 & Exposure & Shining a light & Mestizo/a nation joins the civil rights movement. \\
\hline 29 & Transfiguration & Become anew & $\begin{array}{l}\text { Mestizo/a nation identifies themselves as } \\
\text { Chicano/a. }\end{array}$ \\
\hline 30 & Punishment & Imposter loses home & Chicano/as and Border people refuse to assimilate. \\
\hline 31 & Wedding & Celebration & Reclamation of Aztlán. \\
\hline
\end{tabular}

Figure 2. Propp functions applied to Aztlán. There have been different interpretations and definitions of these stages of the Propp sequence, but they share the basic structure. Here, in the final column, I suggest how the stages of Aztlán's peregrination can be mapped to Propp's Sequence. 
founding figure of the new Mexico nation. Some historians credit La Malinche with saving her people from the Aztecs during her time assisting and translating for Hernán Cortés, by influencing him to be more humane during the conquering of this New World. Many Christians commend her for her part in bringing Christianity from Europe to this conquered region.

What is known is that La Malinche, Malintzin, or Doña Marina-her baptized name-was once one of twenty slaves gifted to Cortés. Throughout their years together, she rose in rank, eventually replacing other trusted advisors, and is portrayed in codices as the right-hand woman to Cortés, equal to him, by the size and repetition of her appearance in these codices (Coerver, Buffington, and Pasztor 2004, p. 200). How or why she earned such standing, as with the location and meaning of Aztlán, is up for debate. What is most important is that when she bore Martin, Cortés' son-the first mestizo, or people of indigenous and European descent-Malintzin, in many Mexican's eyes, also became the mother of a new nation. Eventually, she married one of Cortés' soldiers, Juan de Jaramillo and moved to Spain with him, where she was received by the Spanish court (Figueroa and Melgar 1985, p. 295). Despite this, she is still also widely viewed today as a traitor to her native people. The fact remains that La Malinche was a woman enslaved between two cultures, helping to initiate a series of historical events that would define a space and a people, much like her, straddled between cultures.

After Cortés invaded Mexico in 1519 and conquered the Aztec empire, migrants began settling in the region, once considered Aztlán, and making it their home. At the time, the area was part of the Kingdom of New Spain with a sparse population. This region of New Spain was in a transition and diasporic flux with its mismatched indigenous groups and Spanish settlers, disrupting an indigenous way of life that had been in existence prior to this invasion of land and identity. This position both geographically and philosophically remained in an in-between state, lasting well into the nineteenth century.

During the early nineteenth century, the US expanded steadily in accordance to the theory of Manifest Destiny, acquiring large areas of land and desirable territory that would redefine the US-Mexico border. The influx of people and constant conflicts in the region erupted into the Mexican-American War, which began in 1846 and ended in 1848, followed by the Treaty of Guadalupe Hidalgo, in which the US acquired Aztlán and what is referred to today as the American Southwest.

For centuries, this specific area of the Kingdom of New Spain and the people that inhabited it were mostly free and loosely governed. After the Treaty of Guadalupe Hidalgo, the region remained in a state of diasporic flux, insomuch that it was a place of constant transition. Most of the people living along the American Southwest never left throughout the acquisitions and transitions of this territory-New Spain, Texas, New Mexico, Arizona, California, and Mexico. According to scholar and historian James Clifford, "there is no natural shape to configuration" (2001, p. X) Clifford postulates that there are some indigenous populations that have remained in one place and the environment has changed around them, and these deep histories cannot be denied by "urbanization, habitation, reindigenization, sinking roots, moving on, invading, and holding on" (2001, p. 183). The mestizos-Spanish and American Indian mixed-race individuals-of Mexico and America were trying to figure out their new space, culture, and language, without abandoning their inner-homeland-their Aztlán-that once joined these two areas. The succession of events that followed challenged the Treaty's promises and the people along the border for the many decades to come, as they went through another major transition and what may be understood as a double hybridization.

During the Great Depression of the 1930s, somewhere around 600,000 Mexican people and those ethnically resembling them in appearance were repatriated to Mexico, the status of their citizenship disregarded (Perea 1997). A couple decades later, another 1-1.3 million were repatriated during Operation Wetback (García 1980). Many died during deportation. Busloads of deportees were dropped off in the middle of the Mexican desert where they were left to fend for themselves. This "large-scale clampdown" of "illegal aliens" from Mexico during 1954-1955, ironically, overlapped with the Bracero Program (1942-1964), a "binational initiative" that was established to aid and promote seasonal migration of Mexican laborers for US farming needs (Samora 1971). It was apparent around this time that the millions of people living along the American Southwest border were living in a transcultural region between two countries that would never fully accept this double hybridized population.

\section{Chicano/a Movement}

Shortly after the repatriation movement of Operation Wetback, these unAmericanized-American people without a home and without an identity proclaimed themselves "Chicano/as" They realized they were being intentionally left out of the American ideology. Many were being sent "back" to Mexico whether they were Mexican or not, and the ones that did stay were left with categories and definitions that did not define them, like Latino/as and Hispanics. They never left the Border, but the 
Borders in Globalization Review | Volume 1 | Issue 1 | Fall 2019

Muñoz-Hunt, "Aztlán: From Mythos to Logos in the American Southwest"

land and politics surrounding them had changed. As Terry Goldie asserts, these types of populations became "essential non-participants" (1989, p. 172). It was at this time that they started speaking up, reclaiming their land and identity-as Chicano/asaccording to the Handbook of Texas:

Inspired by the courage of the farmworkers, by the California strikes led by César Chávez, and by the Anglo-American youth revolt of the period, many Mexican-American university students participated in a crusade for social betterment that was known as the Chicano Movement. They used Chicano to denote their rediscovered heritage, their youthful assertiveness, and their militant agenda. Though these students and their supporters used Chicano to refer to the entire Mexican-American population, they understood it to have a more direct application to the politically active parts of the Tejano community (De Leon 2010, p. X).

Scholar Rafaela Castro has defined three possible origins of the term, as discussed by Bauerle and Simmen. First, "Chicano" may have originated from the Mexican city of Chihuahua. In El Paso, Texas, the people from la frontera or the border of Chihuahua are sometimes referred to as Fron-Chis, combining the first part of the Spanish word frontera (Fron-) with the first part of the city name Chihuahua (-Chi). Therefore, "Chicano" could derive from the city name Chihuahua and Mexicano (Chi- and -cano). Second, Chicano may come directly from the indigenous name of the people, Mexica, using the Nahuatl pronunciation of "sh" or "ch" for x. A third possibility is that Chicano comes from the Spanish word chico/a meaning little boy/girl, an Anglo-American term primarily used in the American Southwest in an effort to degrade a Mexican American (Simmen and Bauerle 1969, pp. 225-230). The last explanation might suggest why older Mexican Americans were reticent to adopt the term, although the term "Chicano" is now commonplace.

Much like La Malinche and Aztlán, the origins of the term have been widely debated. Today, Chicano/a is a widely accepted neologism and the direct result of a history of transculturation, migration, conquest, hybridization, and double hybridization that transpired over hundreds of years. Originally, like De Leon mentions, it was a term to describe the working-class Mexican Americans. In the beginning of its reclamation, the term became a generational divide amongst Mexican American students, activists, and the older Mexican American generation, and further separated Mexican Americans from other Latino/a groups. Overall, the goal for self-proclaimed Chicano/as was to organize and recast its people and homeland.

Besides the geopolitical use of the term, "Chicano" as an ethnonym has served a multitude of purposes throughout the American Southwest. The poet and writer Tino Villanueva traced its first use to 1911, before the Chicano Movement, as referenced by anthropologist José Limón in a report, "Hot Tamales" for La Crónica, a Spanish-language newspaper (González 1996). Like Aztlán, Chicano/a became the collective-unconscious homeland, in an effort to define the intra-history and geocultural properties of a borderless Spanish-Mexican-American-mestizo space (Simmen and Bauerle 1969, pp. 225-230). "Chicano" was used to carve out a niche without having to identify with the term and categorization of Hispano (Spanish) or Latino (Iberian, French, Italian, or Romanian).

With a new double-hybrid identification and term to serve the former people of Aztlán, it was only fitting that a new hybrid language also be adopted after two hundred and fifty years of Spanish/Anglo colonization and transculturation. Chicano Spanish slowly made its way into existence. Today, after much Americanization, it is known as "Spanglish," a widely spoken version of mixed Spanish and English now thriving throughout the American Southwest border. In "How to Tame a Wild Tongue," from her book Borderlands/La Frontera: The New Mestiza, Gloria Anzaldúa analyzes how Chicano Spanish further separated Chicano/as from other Latino/as:

\begin{abstract}
Chicanas who grew up speaking Chicano Spanish have internalized the belief that we speak poor Spanish. It is illegitimate, a bastard language. And because we internalized how our language has been used against us by the dominant culture, we use our language differences against each other (2012, p. 38).
\end{abstract}

The Chicano/a Movement focused primarily on the population of Mexican Americans differentiating themselves from the Latino/a population and Hispanic population, which often included it in a homogeneity that the people of the movement recognized as imprecise and inaccurate. With this rising population no longer wanting to exist without a language, home, identity, and voice, the Chicano Movement took center stage throughout the 1960s and 1970s, after a series of events compelled it to do so.

Some historians trace this collective identity to the post-Mexican-American War period, with a range of resistances, depicted in the oral and musical accounts of resistance, and slowly, a sense of Mexican Americanness started to develop in the American Southwest. With outside tensions rising and Mexican-American communities increasing, a collective identity deepened, further separating this new culture from every other culture and conquest the area had known. Organizations such The League of United Latin American Citizens (LULAC) began helping middle-class Mexican-American 
families foster community economic development through education and work ethic. In California, LULAC worked to end segregation and continued its fight to secure the opportunities that many Mexican-American World War II veterans had fought to achieve, politicizing their existence and resisting the perceived Anglo-American hegemony within the military (Rivas-Rodríguez 2005). Despite the growth of these efforts, it is what did not happen after the war that was the catalyst for the Chicano Movement to gain the fervor and momentum it needed to leave a lasting impression and reclaim Aztlán for generations to come.

Mexican-American serviceman, Félix Longoria, was killed in the Philippines during World War II. When his body was returned home to Three Rivers, Texas, in 1949, the local funeral parlor refused to host the wake because they feared a lack of future business if they were to provide service to Mexican Americans. This controversy drew national attention, and then-senator Lyndon B. Johnson intervened and organized Longoria's burial at Arlington National Cemetery (Carroll 2003). Though this solved the immediate problem of Longoria's burial, it did not address the racial tensions rising throughout the American Southwest.

Like LULAC, other organizations across the American Southwest began emerging, filling the need and void of the Mexican-American community during the 1940s and 1950s. With the growing number of Mexican-American organizations and the establishment of Spanish-language newspapers, radio, and TV stations, Mexican-American involvement was reaching the political system at every level (Meier and Gutiérrez 2000). The combination of various efforts during the Chicano Movement helped bring the Chicano/as culture and community into the national consciousness, understanding it finally as an oppressed and exploited group that had been conquered and colonized twice, yet never lost its connection to its indigenous roots and land. According to Hector Calderón, European and Latin American scholars, along with Chicano/a critics, started to recognize the Chicano/a culture as a "social group that has given the distinctive cultural feature to the American West and Southwest" (Calderón 1990, p. 232). Calderón goes on to say that the Chicano Renaissance was developing organically before the Chicano Movement and before the term "Chicano" became mainstream

in oral and written form since the Texas-Mexican War (1836) with greater awareness of cultural differences from Mexico after the US-Mexican War (1846-48), although colonial Novohispano and Mexican cultures in this region date back to the mid-sixteenth century and beyond (Calderón 1990, p. 232-235).
The literature produced at that time could realistically belong to either Spain or Mexico because of their closer ideological relationship in regard to each specific country.

Nevertheless, critic Ignacio M. García of Chicanismo: The Forging of a Militant Ethos among Mexican Americans establishes that the Chicano Renaissance since the 1960s can be divided into four different phases in keeping with critical practice: first, the "critical phase" that takes a look at "historical records and scholarly representations" with attention to assimilation and acculturation within the Chicano/a community; second, the "collective unconscious phase" stemming from the intra-historical perspective of the Chicano/a community; third, the "reclamation and celebration phase" of "Mexican cultural traditions and legacies" within the Chicano/a community; lastly, the "Aztlán phase," where activists have become cultural workers focused on the liberation of the Chicano/a community (García 1980, pp XX).

\section{Chicano/a Aztlán}

In 1967, the poem, "I Am Joaquin" by Corky Gonzales rallied together many Mexican Americans who identified with Joaquin and his struggle to forgo his culture for economic stability but then came full circle to understand his place not yet realized in American Aztlán. Two years later, Gonzales would go on to host the First National Chicano Youth Liberation Conference in Denver, where Alurista read his poem that located, captured, and reclaimed the Chicano/as' homeland, Aztlán, in "El Plan Espiritual de Aztlán” (Anaya and Lomeli 1989, p. 1) (Figure 3).

"El Plan," as it was often abbreviated, called for "reclamation of culture, language, pride, and identity" and the crowd in attendance "rallied around Alurista's depiction of Aztlán." Alurista is accredited with being the first writer with multilingual works published, paving the way for many such writers today. His use of multiple languages is derived from his belief in the blending of cultures. He further explained, in an interview with Juan Bruce-Novoa, "The historical time-space in which we live is going to focus on this terrrenal [earthly] belly button of consciousness between Hispanic America and Anglo-Saxon North America. Amerindia is going to bloom. That's inevitable" (cited in Wood 2007, p. 15). These poems and their poets became the standard for both grassroots-level and academic poets. They are considered some of the most influential leaders in the Chicano Movement, inspiring others to take action a step further by finding strength within their dual culturalism. They gave these grassroots efforts a voice and philosophy that were eventually heard across academia. 
Borders in Globalization Review | Volume 1 | Issue 1 | Fall 2019

Muñoz-Hunt, "Aztlán: From Mythos to Logos in the American Southwest"

In the spirit of a new people that is conscious not only of its proud historical heritage but also of the brutal "gringo" invasion of our territories, we, the Chicano inhabitants and civilizers of the northern land of Aztlan from whence came our forefathers, reclaiming the land of their birth and consecrating the determination of our people of the sun, declare that the call of our blood is our power, our responsibility, and our inevitable destiny.

We are free and sovereign to determine those tasks which are justly called for by our house, our land, the sweat of our brows, and by our hearts. Aztlan belongs to those who plant the seeds, water the fields, and gather the crops and not to the foreign Europeans. We do not recognize capricious frontiers on the bronze continent.

Brotherhood unites us, and love for our brothers makes us a people whose time has come and who struggles against the foreigner "gabacho" who exploits our riches and destroys our culture. With our heart in our hands and our hands in the soil, we declare the independence of our mestizo nation. We are a bronze people with a bronze culture. Before the world, before all of North America, before all our brothers in the bronze continent, we are a nation, we are a union of free pueblos, we are Aztlan.

For La Raza, everything! Outside La Raza, nothing!

\section{Program}

El Plan Espiritual de Aztlan sets the theme that the Chicanos (La Raza de Bronze) must use their nationalism as the key or common denominator for mass mobilization and organization. Once we are committed to the idea and philosophy of El Plan de Aztlan, we can only conclude that social, economic, cultural, and political independence is the only road to total liberation from oppression, exploitation, and racism. Our struggle then must be for the control of our barrios, campos, pueblos, lands, our economy, our culture, and our political life. El Plan commits all levels of Chicano society - the barrio, the campo, the ranchero, the writer, the teacher, the worker, the professional to La Causa.

\section{Nationalism}

Nationalism as the key to organization transcends all religious, political, class, and economic factions or boundaries. Nationalism is the common denominator that all members of La Raza can agree upon.

\section{Organizational Goals}

1. UNITY in the thinking of our people concerning the barrios, the pueblo, the campo, the land, the poor, the middle class, the professional -all committed to the liberation of La Raza.

2. ECONOMY: economic control of our lives and our communities can only come about by driving the exploiter out of our communities, our pueblos, and our lands and by controlling and developing our own talents, sweat, and resources. Cultural background and values which ignore materialism and embrace humanism will contribute to the act of cooperative buying and the distribution of resources and production to sustain an economic base for healthy growth and development Lands rightfully ours will be fought for and defended. Land and realty ownership will be acquired by the community for the people's welfare. Economic ties of responsibility must be secured by nationalism and the Chicano defense units.

3. EDUCATION: must be relative to our people, i.e., history, culture, bilingual education, contributions, etc Community control of our schools, our teachers, our administrators, our counselors, and our programs.

4. INSTITUTIONS: shall serve our people by providing the service necessary for a full life and their welfare on the basis of restitution, not handouts or beggar's crumbs. Restitution for past economic slavery, political exploitation, ethnic and cultural psychological destruction and denial of civil and human rights. Institutions in our community which do not serve the people have no place in the community. The institutions belong to the people.

5. SELF-DEFENSE: of the community must rely on the combined strength of the people. The front line defense wil come from the barrios, the campos, the pueblos, and the ranchitos. Their involvement as protectors of their people will be given respect and dignity. They in turn offer their responsibility and their lives for their people. Those who place themselves in the front ranks for their people do so out of love and carnalismo. Those institutions which are fattened by our brothers to provide employment and political pork barrels for the gringo will do so only as acts of liberation and for La Causa. For the very young there will no longer be acts of juvenile delinquency, but revolutionary acts.

6. CULTURAL values of our people strengthen our identity and the moral backbone of the movement. Our culture unites and educates the family of La Raza towards liberation with one heart and one mind. We must insure that our writers, poets, musicians, and artists produce literature and art that is appealing to our people and relates to our revolutionary culture. Our cultura values of life, family, and home will serve as a powerful weapon to defeat the gringo dollar value system and encourage the process of love and brotherhood.

7. POLITICAL LIBERATION can only come through independent action on our part, since the two-party system is the same animal with two heads that feed from the same trough. Where we are a majority, we will control; where we are a minority, we will represent a pressure group; nationally, we will represent one party: La Familia de La Raza!

\section{Action}

1. Awareness and distribution of El Plan Espiritual de Aztlan. Presented at every meeting, demonstration, confrontation, courthouse, institution, administration, church, school, tree, building, car, and every place of human existence.

2. September 16 , on the birthdate of Mexican Independence, a national walk-out by all Chicanos of all colleges and schools to be sustained until the complete revision of the educational system: its policy makers, administration, its curriculum, and its personnel to meet the needs of our community.

3. Self-Defense against the occupying forces of the oppressors at every school, every available man, woman, and child.

4. Community nationalization and organization of all Chicanos: El Plan Espiritual de Aztlan.

5. Economic program to drive the exploiter out of our community and a welding together of our people's combined resources to control their own production through cooperative effort.

6. Creation of an independent local, regional, and national political party.

A nation autonomous and free - culturally, socially, economically, and politically- will make its own decisions on the usage of our lands, the taxation of our goods, the utilization of our bodies for war, the determination of justice (reward and punishment), and the profit of our sweat.

Figure 3. "El Plan Espiritual de Aztlán." (Gonzales and Urista 1969, 5) 
To examine its symbology and philosophical significance, Aztlán must be viewed as a symbol as much as a myth, while simultaneously accepting that the Aztlán at the end of the Chicano Movement, the Aztlán today, is the Aztlán that has always existed. Aztlán has evolved from "mythos to logos," from a social phenomenon manifesting itself into a persuasive movement and acceptance amongst the Chicano/a nation struggling to come to grips with their role in a new world (Pina 1989, p. 45). Aztlán became the most powerful symbolic ideology during the Chicano/a identification and unification process. It was adopted as the alternative term for the American Southwest, but more specifically, the region along the US-Mexico border. Aztlán thus became a specific geo-cultural space, a Chicano nation, positioned between but still separate from the US and Mexico. Reinforced within its own ideology and rooted in its indigenous past, Aztlán metamorphosed beyond borders, in a collective resistance to the hegemony asserted by the US. Aztlán was all-inclusive, ever since the time when the seven Aztec tribes united. Meanwhile, Aztlán rejected assimilation, racism, and the overall socioeconomic, political, and cultural insubordination that has been boiling over in the American melting pot since the Treaty of Guadalupe Hidalgo. During the Chicano Movement, Aztlán symbolized the reclamation of a sense of place and territory that has always belonged to the people along the Border (Acuna 2000). Over time, Aztlán has become a symbolical concept for a multitude of indigenous movements, not just during the reconfiguration of the US-Mexico border, but for almost the entire two centuries since the signing of the Treaty of Guadalupe Hidalgo.

A couple of decades later in 2000, scholar Charles Truxillo advanced the concept of Aztlán and predicted a sovereign Hispanic nation in the American Southwest, according to historian Frank Zoretich. Though at the time, Truxillo's beliefs seemed a bit radical, they also captured the residual mood and sentiment from some critics during this post-Chicano Movement. Today, some American Southwest people still agree with Truxillo that "Native-born American Hispanics feel like strangers in their own land" (2000, A1). One could argue that the República del Norte and Reconquista movements are all offshoots of the Chicano Movement's Aztlán. In an interview with In Search of Aztlán, Jose Angel Gutierrez, a political science professor at the University of Texas at Arlington, further explained the reasoning behind these movements and what they hoped to gain with a sovereign Hispanic nation:

We're the only ethnic group in America that has been dismembered. We didn't migrate here or immigrate here voluntarily. The United States came to us in succeeding waves of invasions. We are a captive people, in a sense, a hostage people. It is our political destiny and our right to self-determination to want to have our homeland back. Whether they like it or not is immaterial. If they call us radicals or subversives or separatists, that's their problem. This is our home, and this is our homeland, and we are entitled to it. We are the host. Everyone else is a guest (Gutíerrez 1999).

Similarly, the term "Hispanic" to this day remains controversial amongst many Chicano/as, Mxican Americans, and Latinos.

Though there are different meanings of the word "Hispanic," depending on the source, the term is often used to refer to descendants of Spain and does not properly serve the population of the American Southwest, with its multiracial Spanish-Mexican-American-Native-Mestizo roots. Like Aztlán, the geoculture of the American Southwest is hard to define, but scholars and critics will agree that its borders, labels, religion, culture, language, and history are slowly becoming a double hybridism reconciled from centuries of major historical changes.

After "El Plan de Aztlán" was presented by Alurista at the first National Chicano Youth Liberation Conference and adopted by the Chicana/o people, Aztlán has continued to live and function as the Chicano/a homeland whether or not it is a factual or mythical place. By applying the Propp Sequence and determining how this mythical homeland and story had turned into functional philosophy and reclaimed geocultural location, it is easy to understand how Aztlán has surpassed the test of time. Aztlán functions as a truth from mythos to logos, physically in the American Southwest and emotionally in the hearts and minds of the Chicano/a people, and according to William James, what functions as a truth, is truth.

Aztlán, the home of the Aztec, Mexican, and Chicano/a, alienated from Americanness but still umbilically tied to its Pre-Colombian homeland, does not belong to either place. Regardless of the border peoples' self-identification as Tejanos, Mexicano/as, Mexican Americans, Spanish, Spanish Americans, Americans, Latino/as, or Chicano/as deriving from the ancient cultures, Spain, or the US, a new double hybrid has emerged. While the original location of Aztlán can be debated, Aztlán has survived two periods of hybridization: first, by the conquering of the indigenous peoples by Spanish imperialism, resulting in the Mexican mestizo/a population; and then secondly, by American imperialism over these mestizo/a populations, resulting in the Mexican-American mestizo/a population.

During the 1980s, the popular concept of double colonization was first introduced, referring to the fact that within formerly colonized, and often, indig- 
Borders in Globalization Review | Volume 1 | Issue 1 | Fall 2019

Muñoz-Hunt, "Aztlán: From Mythos to Logos in the American Southwest"

enous societies, women were colonized twice: first, through imperial ideology and, secondly, through patriarchal ideology (Ashcroft, Griffiths, Tiffin 1997, p. 233). Duplication, as a result, is the exact copy and repetition of an object, but when considering the complexity of cultures, this is too simplistic an application. By nature, this is not what occurs during colonization, but rather, aspects of assimilation and epistemic violence take place.

A decade after double colonization emanated, Homi Bhabha established hybridity as a theoretical development in The Location of Culture. Hybridization, as the doubling of cultures through the presence of the colonizer and colonized, intricately relating culture with place, became the essence of these societal conditions (Ashcroft, Griffiths, Tiffin 1997 p. 137). The duality of these cultures is not necessarily Manichean in nature, but rather, it is the opposition between the "putative superiority of the European and the supposed inferiority of the native" (Goldie 1989, p. 172). Hybridity is neither duplication nor binary. As Clifford asserts, it is an example of cultures in flux and in constant motion (2001, p. 468). Insomuch as these indigenous voices cannot be put into a single collective category, they will continue to define and redefine themselves.

Understanding cultures and locations is acknowledging the fact that each culture and each location is different, and therefore, the combination of culture and location produces entirely different variables, from one to the next, such as Aztlán. Thus, the various circumstances that affect these variables, like scholar Diana Brydon's concept of "disruption" must be taken into consideration (1991, pp. 184-188). With the enduring history, myth, reclamation, and truth of Aztlán demonstrating the transformation of border culture across eras, the concept of double hybridization opens conversation further for examination of how the shapeless configuration may explain extant hybrid populations. Aztlán began as the homeland of seven different tribes and was reclaimed as the homeland, both physically and emotionally, by the population living in the American Southwest today, as seen in the art, literature, and music it has influenced. Wherever or however Chicano/a culture and identity can be formed, rediscovered, or reinvented, Aztlán remains a part of them along their journey.

\section{Works Cited}

Acuña, Rodolfo. 2000. Occupied America: A History of Chicanos. 4th ed. New York: Longman.

Anaya, Rudolfo A. and Lomeli, Francisco. 1989. Aztlán: Essays on the Chicano Homeland. Albuquerque NM: Academia/El Norte Publications.
Anzaldúa, Gloria. 2012. Borderlands: La Frontera and the New Mestiza. San Francisco CA: Aunt Lute Books.

Ashcroft, Bill, Gareth Griffiths, and Helen Tiffin. 1997. The Post-Colonial Studies Reader. Routledge.

Barnouw, Victor and Lynn I. Perrigo. 1960. Our Spanish Southwest. Dallas, Banks Upshaw \& Co.

Bhabha, Homi K. The Location of Culture. Routledge, 2006.

"Boturini, Codex." 1530-1541. Códices de México. Instituto Nacional De Antropologia e Historia. Available: www. codices.inah.gob.mx/pc/index.php

Brydon, Diana. 1991. "The White Inuit Speaks: Contamination of Literary Strategy," in Past the Last Post: Theorizing Post-colonialism and Post-modernism. New York and London: Harvester Wheatsheaf.

Calderón, Hector. 1990. "At the Crossroads of History, on the Borders of Change: Chicano Literary Studies Past, Present, and Future." In Left Politics and the Literary Profession, edited by Lennard J. Davis and M. Bella Mirabella. New York: Columbia University Press.

Carroll, James Patrick. 2003. Felix Longoria's Wake: Bereavement, Racism, and the Rise of Mexican-American Activism. Austin: University of Texas Press.

Chávez, John. 1989. "Aztlán, Cíbola, and Frontier New Spain," in Aztlán: Essays on the Chicano Homeland, edited by Rudolfo A. Anaya and Francisco Lomeli. Albuquerque: Academia/El Norte Publications.

Clifford, James. 2001. "Indigenous Articulations." The Contemporary Pacific 3/2: 468-490. http://doi.org/ d77sk5

Coerver, Buffington, and Pasztor. 2004. Mexico: an Encyclopedia of Contemporary Culture and History. ABC-CLIO: 200.

De Figueroa, Alfonso and Melgar. 1985. "Historia Genealógica de la Casa de Basabe y Sus Enlazados." Estudios Genealógicas y Heráldico, Vol. 1. Madrid, Spain: Asociacion Española de Estudios Genealogicos y Heraldicos,

De León, Arnoldo. 2010. "Chicano." Handbook of Texas Online. Available: http://www.tshaonline.org/ handbook/online/articles/pfc02.

Ellis, Florence Hawley. 1968. "What Utaztecan Ethnology Suggests of Utaztecan Prehistory," in Utaztekan Prehistory, edited by Earl H. Swanson, Jr., Occasional Papers of the Idaho State University Museum, no. 22 Pocatello: Idaho State University.

García, Juan Ramón. 1980. Operation Wetback: The Mass Deportation of Mexican Undocumented Workers in 1954. Westport: Greenwood.

Goldie, Terry. 1989. Fear and Temptation: The Image of the Indigene in Canadian, Australian, and New Zealand Literature. Kingston: McGill-Queens University Press.

González, Félix Rodríguez. 1996. Spanish Loanwords in the English Language. A Tendency towards Hegemony Reversal. Berlin: Mouton de Gruyter.

Gonzales, Rodolfo and Urista, Alberto. 1969. "El Plan Espiritual de Aztlán.” El Grito del Norte 11/9 (July 6). 
"José Angel Gutiérrez Interview." In Search of Aztlán, Aug. 8, 1999. Available: http://www.insearchofaztlan.com/ gutierrez.html

Hodge, Bob and Mishra, Vijay. 1991. The Dark Side of the Dream. London: Allen and Unwin. 363.

James, William. 1963. Pragmatism, and Other Essays. Washington Square Press.

Lux, Guillermo and Maurilio E. Vigil. 1989. "Return to Aztlán: The Chicano Rediscovers His Indian Past," in Aztlán: Essays on the Chicano Homeland, edited by Rudolfo A. Anaya and Francisco Lomeli. Albuquerque: Academia/El Norte Publications.

Maffie, James. 2014. Aztec Philosophy: Understanding a World in Motion. Louisville: UP of Colorado.

Mann, Charles C. 2005. 1491: New Revelations of the Americas Before Columbus. New York, Alfred A. Knopf: 121.

Meier, Matt S. and Margo Gutiérrez. 2000. Encyclopedia of the Mexican American Civil Rights Movement. Westport: Greenwood.

Mignolo, Walter D. 1995. The Dark Side of the Renaissance: Literacy, Territoriality and Colonization. Ann Arbor: University of Michigan Press.

Moraga, Cherrie. The Last Generation: Prose and Poetry. Boston, South End, 1993.

Nuccetelli, Schutte, and Bueno. 2013. A Companion to Latin American Philosophy Wiley Blackwell.
Perea, Juan F. 1997. Immigrants Out!: The New Nativism and the Anti-Immigrant Impulse in the United States. New York: New York University Press.

Pina, Michael. 1989. "The Archaic, Historical and Mythicized Dimensions of Aztlán," in Aztlán: Essays on the Chicano Homeland, edited by Rudolfo A. Anaya and Francisco Lomeli. Albuquerque, Academia/El Norte Publications.

Propp, Vladimir. 1969. Morphology of the Folk Tale. University of Texas Press.

Riley L. Carroll. 1971. "Early Spanish-Indian Communication in the Greater Southwest." New Mexico Historical Review 46/4: 286-87. Available: https://ejournals.unm. edu/index.php/nmhr/article/view/610

Rivas-Rodríguez, Maggie. 2005. Mexican Americans and World War II. Austin, University of Texas Press.

Romero, Rolando. 2005. Feminism, Nation and Myth: La Malinche. Houston: Arte Publico Press.

Samora, Julian. 1971. Los Mojados: The Wetback Story. Notre Dame: University of Notre Dame Press.

Simmen, Edward R. and Richard F. Bauerle. 1969. "Chicano: Origin and Meaning." American Speech 44/3: 225-30. http://doi.org/cr6v9v

Wood, Jamie Martinez. 2007. Latino Writers and Journalists. New York: Facts on File.

Zoretich, Frank. 2000. "New Mexico Will Secede to New Nation, Prof Says." Albuquerque Tribune. A1. 